\title{
Перший досвід використання периферичної екстракорпоральної мембранної оксигенації в дитини з тяжкою дихальною недостатністю
}

\author{
Сафонов В. В. ${ }^{1}$, Секелик Р. І. ${ }^{1}$, Висоцький А. Д. ${ }^{1}$, Авєтян А. М. ${ }^{2,1}$, \\ Мотречко О. О. ${ }^{1}$, Ємець І. М., ${ }^{1,2}$ \\ ${ }^{1}$ ДУ «Науково-практичний медичний центр дитячої кардіології та кардіохірургії МОЗ України» (Київ) \\ ${ }^{2}$ Національна медична академія післядипломної освіти імені П. Л. Шупика (Київ)
}

\begin{abstract}
Екстракорпоральна мембранна оксигенація (ЕКМО) є важливим методом у лікуванні гострої серцевої та дихальної недостатності. Периферична методика вено-артеріального ЕКМО полягає в заборі, газообміні та поверненні крові через канюлі, встановлені в периферичні судини.

Мета роботи - проаналізувати власний досвід використання вено-артеріального ЕКМО з периферичним методом канюляції в дитини з тяжкою дихальною недостатністю після операції Росса-Конно.

Матеріали і методи. У статті розглядається клінічний випадок пацієнта з важкою дихальною недостатністю, що потребував підключення апарату ЕКМО з канюляцією правої загальної сонної артерії та правої внутрішньої яремної вени.

Результати та обговорення. Під час проведення ЕКМО вдалося стабілізувати і покращити стан дитини, що зафіксовано лабораторними та інструментальними методами дослідження.

Висновки. Екстракорпоральна мембранна оксигенація - це ефективний метод боротьби з гострою дихальною недостатністю, що забезпечує сприятливі умови для подолання інфекції та відновлення функції легень. Периферична методика канюляції дозволяє уникнути багатьох ускладнень, які виникають при центральній канюляції.
\end{abstract}

Ключові слова: екстракорпоральна мембранна оксигенація, периферична канюляція, гостра дихальна недостатHicmb.

Екстракорпоральна мембранна оксигенація (ЕКМО) є важливим методом у лікуванні гострої серцевої та дихальної недостатності [1]. За даними реєстру Організації Екстракорпоральної Підтримки Життєдіяльності на 2018 р., з часу першої публікації про успішне застосування ЕКМО в 1972 р. у дорослих і в 1974 р. у дітей віком до одного року було зареєстровано понад 100000 випадків підключень ЕКМО, з них 43000 дитячих [2-4]. Екстракорпоральна мембранна оксигенація - це методика життєзабезпечення, що грунтується на пролонгованому штучному кровообігу [1]. Периферична методика вено-артеріального ЕКМО полягає в заборі, газообміні та поверненні крові через канюлі, встановлені в периферичні судини [5]. У нашому випадку було проведено канюляцію правої загальної сонної артерії та правої внутрішньої яремної вени.

Мета роботи - проаналізувати власний досвід використання вено-артеріальної мембранної оксигенації з периферичним методом канюляції в дитини з тяжкою дихальною недостатністю після операції Росса-Конно.

Матеріали і методи. Дитина віком 7 місяців, вагою 6,5 кг поступила до ДУ «НПМЦДКК МОЗ України» 3 діагнозом комбінована аортальна вада з перевагою не- достатності, виражена систолічна дисфункція лівого шлуночка, фіброеластоз ендокарда лівого шлуночка. 3 анамнезу відомо, що пацієнту в першу добу життя було проведено балонну дилатацію клапана аорти та пластику клапана аорти у віці 1 місяць. Згідно з даними ехокардіографії, фракція викиду лівого шлуночка (ФВ ЛШ) становила 20\%, кінцево-діастолічний індекс лівого шлуночка (КДІ ЛШ) - 219,6 мл/м². Також було виявлено виражену недостатність із максимальним градієнтом на аортальному клапані 66 мм рт. ст. Пацієнту було виконано операцію Росса-Конно, що пройшла планово, без ускладнень. 3 огляду на вихідний важкий стан, відразу після зупинки апарата штучного кровообігу пацієнт отримав таку інотропну підтримку: допамін 5 мкг/кг/хв., добутамін 5 мкг/кг/хв., адреналін 0,005 мкг/кг/хв. і левосимендан 0,2 мкг/кг/хв. Грудина була планово залишена незведеною на 2 доби. На 7-му добу після операції пацієнт був екстубований, при цьому фракція викиду лівого шлуночка відновилась і вдалось спочатку зменшити, а потім зовсім припинити інотропну підтримку. На 9-ту добу пацієнта було заінтубовано і переведено на штучну вентиляцію легень (ШВЛ) на фоні прогресування дихальної недостатності та погіршення показників лейкоцитарної 
формули. У загальному аналізі крові були такі показники: лейкоцити $14,7 \times 10^{9} /$ л; еозинофіли - $0 \%$; паличкоядерні - 24\%; сегментоядерні - 62\%; лімфоцити $10 \%$; моноцити - 4\%. На 12-ту добу на фоні швидкого прогресування явищ гіпоксемії та гіперкапнії пацієнта переведено на високочастотну штучну вентиляцію легень (ВЧШВЛ), проте показники газового складу артеріальної крові погіршувалися. При фракційній концентрації кисню в дихальній суміші $100 \%$ вони становили: водневий показник $(\mathrm{pH})-7,23$; парціальний тиск вуглекислого газу в артеріальній крові $\left(\mathrm{pCO}_{2}\right)-$ 75,6 мм рт. ст.; парціальний тиск кисню в артеріальній крові $\left(\mathrm{pO}_{2}\right)-40,9$ мм рт. ст.; насичення артеріальної крові киснем $\left(\mathrm{SaO}_{2}\right)-69 \%$. Також спостерігалася негативна динаміка показників лейкоцитарної формули: лейкоцити $11,9 \times 10^{9} / л$; еозинофіли - 2\%; паличкоядерні - 37\%; сегментоядерні - 53\%; лімфоцити $-5 \%$; моноцити - 2\%. При бактеріоскопічному дослідженні мокроти з верхніх дихальних шляхів на попередній мікроскопії були виявлені Klebsiella pneumoniae i Stenotrophomonas maltophilia.

На 13-ту добу після операції було прийнято рішення про підключення вено-артеріального ЕКМО з периферичним методом канюляції через праву загальну сонну артерію та праву внутрішню яремну вену. Було виконано поперечний розріз шкіри над правою ключицею в ділянці грудинно-ключично-соскоподібного м'яза для доступу до правого судинно-нервового пучка шиї. Мобілізовано та перев'язано в дистальній частині праву загальну сонну артерію та внутрішню яремну вену. Проксимально канюльовано праву загальну сонну артерію прямою армованою канюлею діаметром 3,3 мм і праву внутрішню яремну вену прямою армованою канюлею діаметром 4 мм, підключено апарат екстракорпоральної мембранної оксигенації. Канюлі фіксовано двічі до турнікетів на судинах і до шкіри, шкіра над місцем канюляції була ушита для уникнення місцевих інфекційних ускладнень [6]. На 6-ту добу проведення ЕКМО була виконана заміна контуру.

Під час виконання планової нейросонографії на 11-ту добу виявлено вогнище підвищеної ехогенності, ймовірно гематома, діаметром 20 мм зліва у верхній лобній долі, розташоване перивентрикулярно без зв'язку з порожниною шлуночка. У динаміці через добу гематома в лобній долі зліва збільшувалася, тому було проведено зупинку ЕКМО та деканюляцію.

Під час проведення вено-артеріальної ЕКМО здійснювався постійний контроль показників коагулограми, газового складу крові, ЗАК, біохімічний аналіз крові, моніторинг церебральної пульсоксиметрії, ехокардіографія та нейросонографія. Пацієнт отримував антибактеріальну терапію відповідно до посівів упродовж усього періоду перебування у відділенні інтенсивної терапії. Хворому було призначено цефуроксим натрію, меропенем тригідрат, колістиметат натрію, фосфоміцин натрію, сульфаметоксазол і триметроприм.

Результати та обговорення. Під час проведення ЕКМО вдалося стабілізувати і покращити стан дитини, що зафіксовано лабораторними та інструментальними методами дослідження. На 12-ту добу проведення ЕКМО було прийнято рішення про його зупинку та переведення пацієнта на ВЧШВЛ у зв'язку з виникненням гематоми в лобній долі зліва. Пацієнт знаходився на ВЧШВЛ 41 добу, після чого був переведений на традиційну ШВЛ, що тривала ще 26 діб і дозволила перевести пацієнта на самостійне дихання. Хворий перебував у палаті стаціонару відділення серцевої хірургії протягом 15 діб і в задовільному стані був виписаний додому на 107 добу після операції.

На момент виписки зі стаціонару неврологічний статус дитини був оцінений неврологом. Дитина була при свідомості, реагувала тихим плачем, фотореакції живі, на іграшці погляд не фіксувала, наявна нейросенсорна приглухуватість, лівосторонній центральний геміпарез. Згідно з даними літератури, частота внутрішньочерепних крововиливів при використанні ЕКМО становить 19\% [7]. Найчастіше причинами виникнення внутрішньочерепних крововиливів $є$ антикоагуляційна терапія під час проведення екстракорпоральної мембранної оксигенації [8]. 3 огляду на характер і локалізацію ушкодження головного мозку, гематома в лобній долі зліва не пов'язана з методикою периферичної канюляції $з$ контрлатеральною перев'язкою судин шиї [9].

Через 3 місяці після операції проведено комп'ютерну томографію з реконструкцією судин, на якій виявлено повну облітерацію правого судиннонервового пучка шиї з компенсаторним збільшенням колатеральних судин (рис. 1). Неврологічний статус був повторно оцінений неврологом через 7 місяців. На момент огляду дитина при свідомості, на огляд реагувала руховою активністю. Слух і гострота зору дещо знижені, погляд фіксований, добре стежила за

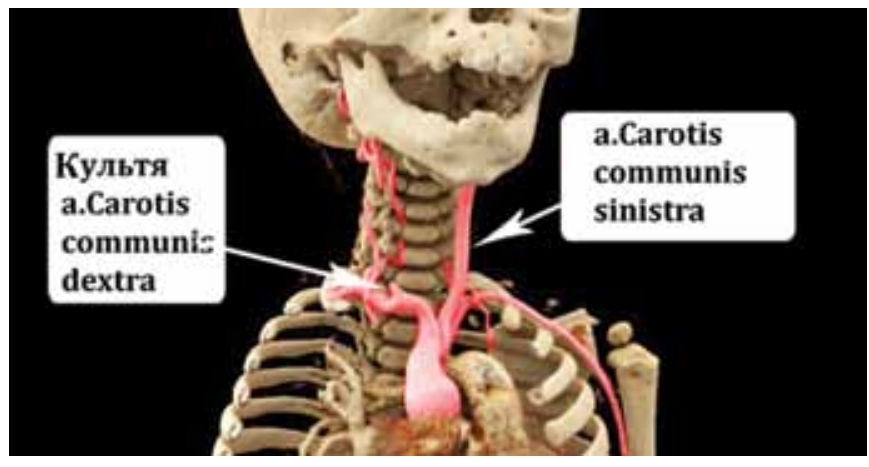

Рис. 1. Комп'ютерна томографія судин шиї з 3D-реконструкцією 
іграшкою, тягнулася та утримувала ії. Спостерігалася збіжна косина за рахунок лівого ока. Обличчя симетричне. Тонус м'язів знижений, переважно в стопах. Легкий центральний геміпарез зліва. Дитина переверталася з живота на спину.

Згідно з даними ехокардіографії, проведеної через 7 місяців, ФВЛШ становила 68\%, КДІЛШ - 63,26 мл/м². Максимальний градієнт на аортальному клапані 4 мм рт. ст. Невеликий стеноз кондуїту легеневої артерії з максимальним градієнтом 24 мм рт. ст. Невелика недостатність мітрального клапана. Залишкова невелика гіпертрофія лівого шлуночка.

Описаний нами випадок є підтвердженням того, що ЕКМО з периферичною методикою канюляції може застосовуватись у дітей першого року життя з важкою дихальною недостатністю $[1-3,10]$. Перевагами такої методики є менша травматизація тканин при канюляції і деканюляції та можливість проведення процедури у відділенні інтенсивної терапії, відсутність ризику ушкодження органів середостіння, особливо в дітей, які мали попередні оперативні втручання $[1,5$, $6,10-12]$. При застосуванні цієї методики існує менша вірогідність розвитку інфекційних ускладнень, інтраопераційної та післяопераційної крововтрати, а також більш швидка активізація пацієнта після відключення від апарату екстракорпоральної мембранної оксигенаціï $[3,5,6,10-12]$.

\section{Висновки}

- Екстракорпоральна мембранна оксигенація - це ефективний метод боротьби з гострою дихальною недостатністю, що дозволяє створити сприятливі умови для подолання інфекції та відновлення функції легень.

- Периферична методика порівняно із центральною методикою підключення ЕКМО дозволяє забезпечити достатній газообмін навіть при використанні канюль менших діаметрів.

- Периферична методика канюляції є ефективним засобом уникнення багатьох ускладнень, які виникають при центральній канюляції.

- Неврологічні ускладнення, що виникли під час проведення ЕКМО, не були пов'язані з методикою канюляції та мали зворотний характер при оцінці неврологічного статусу в динаміці.

\section{Література}

1. Bahrami KR, Van Meurs KP. ECMO for neonatal respiratory failure. Seminars in perinatology. 2005;29:15-23.
2. Hill JD, O'Brien TG, Murray JJ, Dontigny L, Bramson ML, Osborn JJ, Gerbode F. Prolonged extracorporeal oxygenation for acute post-traumatic respiratory failure (shock-lung syndrome): use of the Bramson membrane lung. N Engl J Med. 1972;286(12):629-34.

3. Bennett CC, Johnson A, Field DJ, Elbourne D; UK Collaborative ECMO Trial Group. UK collaborative randomised trial of neonatal extracorporeal membrane oxygenation: follow-up to age 4 years. Lancet. 2001;357(9262):1094-6. https://doi.org/10.1016/S01406736(00)04310-5

4. Extracorporeal Life Support Organization [Internet]. Michigan; c2019 [cited 2019 Jan 30]. Extracorporeal Life Support Registry Report; [about 1 screen]. Available from: https://www.elso.org/Registry/Statistics/ InternationalSummary.aspx

5. Pavlushkov E, Berman M, Valchanov K. Cannulation techniques for extracorporeal life support. Ann Trans Med. 2017;5(4):70. https://doi.org/10.21037/ atm.2016.11.47

6. Extracorporeal Life Support Organization [Internet]. Michigan; c2019. Extracorporeal life support organization (ELSO guidelines); [about 1 screen]. Available from: http:// www.elso.org/resources/Guidelines.aspx

7. Bulas DI, Taylor GA, O'Donnell RM, Short BL, Fitz CR, Vezina G. Intracranial abnormalities in infants treated with extracorporeal membrane oxygenation: update on sonographic and CT findings. AJNR Am J Neuroradiol. 1996;17(2):287-94.

8. Dela Cruz TV, Stewart DL, Winston SJ, Weatherman KS, Phelps JL, Mendoza JC. Risk factors for intracranial hemorrhage in the extracorporeal membrane oxygenation patient. J Perinatol. 1997;17(1):18-23.

9. van Heijst AF, de Mol AC, Ijsselstijn H. ECMO in neonates: neuroimaging findings and outcome. Semin Perinatol. 2014;38(2):104-13. https://doi.org/10.1053/j. semperi.2013.11.008

10. Prodhan P, Stroud M, El-Hassan N, Peeples S, Rycus P, Brogan TV, et al. Prolonged extracorporeal membrane oxygenator support among neonates with acute respiratory failure: a review of the Extracorporeal Life Support Organization registry. ASAIO J. 2014;60(1):63-9. https:// doi.org/10.1097/MAT.0000000000000006

11. Reeb J, Olland A, Renaud S, Lejay A, Santelmo N, Massard G, et al. Vascular access for extracorporeal life support:tipsand tricks. JThorac Dis. 2016;8(Supp14):S35363. https://doi.org/10.21037/jtd.2016.04.42

12. Makdisi G, Wang IW. Extra corporeal membrane oxygenation (ECMO) review of a lifesaving technology. J Thorac Dis 2015;7:E166-76. https://doi.org/10.3978/j. issn.2072-1439.2015.07.17 


\title{
First experience of the usage of peripheral extracorporeal membrane oxygenation in a child with severe respiratory insufficiency
}

\author{
Safonov V. ${ }^{1}$, Sekelyk R. ${ }^{1}$, Vysotskyi A. ${ }^{1}$, Avetyan A. ${ }^{2,1}$, Motrechko O. ${ }^{1}$, Yemets I. ${ }^{1,2}$ \\ ${ }^{1}$ Ukrainian Children's Cardiac Center (Kiev) \\ 2 Shupyk National Medical Academy of Postgraduate Education (Kiev)
}

Extracorporeal membrane oxygenation (ECMO) is a life-supporting technique in the treatment of severe cardiac and respiratory insufficiency. It is based on the prolonged extracorporeal blood circulation. Peripheral venoarterial ECMO involves withdrawing, gas exchange and returning blood through cannulas implanted in peripheral vessels.

Objective. We are interested in analysing our experience of venoarterial membrane oxygenation with peripheral cannulation, which was used in a child aged eight months with severe respiratory insufficiency after the Ross-Konno operation.

Materials and methods. The subject of this article is the patient's case with severe respiratory insufficiency in the early post-operative period because of a bacterial infection. In spite of being transferred to the artificial lung ventilation, the child's condition was worsening and the decision to use ECMO with peripheral cannulation was taken. In this particular case, there was cannulation of the right artery and right inner vein cava. Unfortunately, we had to discontinue ECMO because of a hematoma in the frontal lobe.

Results and discussion. While maintaining ECMO, we managed to improve the patient's condition and make it stable, evidenced by the laboratory and instrumental tests. This case is indicative of the possibility of using ECMO with peripheral cannulation in infants with severe respiratory insufficiency.

Conclusions. ECMO is quite an effective method of treatment of severe respiratory insufficiency, which allows creating favourable conditions to overcome the infection and renew the pulmonary function. As compared with the central technique, the peripheral ECMO ensures sufficient gas-exchange even using cannulas of a smaller diameter. Peripheral cannulation is the efficacious way to avoid complications occurring during the central cannulation. The complications that occurred during venoatrial ECMO were reversible and not associated with cannulation.

Key words: extracorporeal membrane oxygenation, peripheral cannulation, severe respiratory insufficiency. 